University of Nebraska - Lincoln

DigitalCommons@University of Nebraska - Lincoln

Nebraska Cooperative Fish \& Wildlife Research Nebraska Cooperative Fish \& Wildlife Research Unit -- Staff Publications

2006

\title{
Temperature-Caused Fish Kill in a Flowing Great Plains River
}

\author{
Bart W. Durham \\ Texas Tech University \\ Gene R. Wilde \\ Texas Tech University \\ Kevin L. Pope \\ University of Nebraska-Lincoln, kpope2@unl.edu
}

Follow this and additional works at: https://digitalcommons.unl.edu/ncfwrustaff

Part of the Other Environmental Sciences Commons

Durham, Bart W.; Wilde, Gene R.; and Pope, Kevin L., "Temperature-Caused Fish Kill in a Flowing Great Plains River" (2006). Nebraska Cooperative Fish \& Wildlife Research Unit -- Staff Publications. 15. https://digitalcommons.unl.edu/ncfwrustaff/15

This Article is brought to you for free and open access by the Nebraska Cooperative Fish \& Wildlife Research Unit at DigitalCommons@University of Nebraska - Lincoln. It has been accepted for inclusion in Nebraska Cooperative Fish \& Wildlife Research Unit -- Staff Publications by an authorized administrator of DigitalCommons@University of Nebraska - Lincoln. 


\title{
TEMPERATURE-CAUSED FISH KILL IN A FLOWING GREAT PLAINS RIVER
}

\author{
Bart W. Durham,* Gene R. Wilde, and Kevin L. Pope \\ Wildlife and Fisheries Management Institute, Texas Tech University, Box 42125, Lubbock, TX 79409-2125 \\ *Correspondent: bart.durham@ttu.edu
}

\begin{abstract}
On 9 July 2002, while sampling a flowing segment of the North Fork Ninnescah River $10 \mathrm{~km}$ upstream from Cheney Reservoir, Reno County, Kansas, we observed and collected dead and dying specimens of 5 fish species. We attribute the fish kill to high water temperature, which reached $38.0^{\circ} \mathrm{C}$ on this day.
\end{abstract}

RESUMEN-El 9 de julio del 2002, mientras muestreábamos un segmento con corriente del río North Fork Ninnescah, $10 \mathrm{~km}$ río arriba de la presa Cheney, en el condado de Reno en Kansas, observamos y recolectamos cinco especies de peces moribundos y muertos. Atribuimos la muerte de los peces a la alta temperatura del agua registrada ese día, la cual alcanzó los $38.0^{\circ} \mathrm{C}$.

Effects of temperature are generally sublethal, but in extreme cases temperature and associated stressors can directly cause fish mortality (Beitinger et al., 2000). The most commonly reported instances of mortality attributable to high water temperatures are among fishes that become isolated in streambed pools for extended periods (Tramer, 1977; Matthews et al., 1982; Mundahl, 1990) or in receding lakes (Bailey, 1955). Limited volume of these isolated waters makes them susceptible to rapid changes in physical and chemical conditions. Mortality of fishes attributable to high water temperature is believed to be common, although it is infrequently observed in the field (Bailey, 1955). We are aware of only 2 published reports (Huntsman, 1942, 1946) of temperature-induced mortality among fishes in lotic habitats, both of which describe mortality in coldwater streams. The purpose of this paper is to describe observations of a fish kill in a flowing warmwater stream that we attribute to high water temperature. Our account is necessarily observational because the transience of the event, encountered in the field, precluded experimental manipulation.

On 8 and 9 July 2002, we sampled the North Fork Ninnescah River $\left(37^{\circ} 50^{\prime} 41^{\prime \prime} \mathrm{N}\right.$, $97^{\circ} 56^{\prime} 09^{\prime \prime} \mathrm{W}$ ) approximately $10 \mathrm{~km}$ upstream from Cheney Reservoir, Reno County, Kansas. Our purpose was to document the composition of the fish assemblage in relation to habitat variables. We sampled this site for approx- imately one hour, beginning at $1830 \mathrm{~h}$, using 2 seines $(1.8 \times 3.4 \mathrm{~m}$ and $1.8 \times 9.1 \mathrm{~m}$, with 5 mm mesh) and making an effort to sample all available habitat types. Captured fish were preserved in $10 \%$ buffered formalin. Water quality parameters (temperature, dissolved oxygen, conductivity, and turbidity), stream width, stream depth, and current velocity were recorded in each habitat sampled. In addition to our measurements, hourly water temperature and stream discharge measurements were obtained from the U.S. Geological Survey gaging station $(\# 07144780)$ located at the site.

We collected 518 fish representing 9 families and 14 species on 8 July 2002 (Table 1). Red shiner (Cyprinella lutrensis) and sand shiner (Notropis stramineus) were the most common species, collectively representing $80 \%$ of the total catch. Northern plains killifish (Fundulus kansae) and white perch (Morone americana) were the third and fourth most abundant species, respectively. These 2 species combined represented an additional $12 \%$ of collected specimens. All other species individually represented fewer than $2 \%$ of collected specimens. Physical and chemical conditions (mean $\pm S D$ ) recorded at the time of sampling were: water temperature $35.0 \pm 0.17^{\circ} \mathrm{C}$, dissolved oxygen concentration $6.93 \pm 0.17 \mathrm{mg} / \mathrm{L}$, conductivity $1,115 \pm 104 \mu \mathrm{S} / \mathrm{cm}$, and turbidity $69.2 \pm 9.4$ NTU. Mean current velocity was $0.37 \pm 0.08 \mathrm{~m} / \mathrm{s}$, mean stream depth was $20 \pm$ $7.8 \mathrm{~cm}$, and stream width was $34.7 \mathrm{~m}$. 
TABLE 1-Fish collected on 8 and 9 July 2002 from the North Fork Ninnescah River upstream from Cheney Reservoir, Reno County, Kansas. Fish collected on 8 July were alive. Fish collected on 9 July were dead or moribund.

\begin{tabular}{|c|c|c|}
\hline \multirow[b]{2}{*}{ Species } & \multicolumn{2}{|c|}{$\begin{array}{l}\text { Number } \\
\text { collected }\end{array}$} \\
\hline & $\begin{array}{c}8 \\
\text { July }\end{array}$ & $\begin{array}{c}9 \\
\text { July }\end{array}$ \\
\hline Red shiner, Cyprinella lutrensis & 334 & \\
\hline Sand shiner, Notropis stramineus & 90 & \\
\hline Northern plains killifish, Fundulus kansae & 52 & \\
\hline White perch, Morone americana & 12 & 28 \\
\hline Emerald shiner, Notropis atherinoides & 8 & \\
\hline River carpsucker, Carpoides carpio & 7 & 1 \\
\hline Western mosquitofish, Gambusia affinis & 6 & \\
\hline Channel catfish, Ictalurus punctatus & 6 & \\
\hline Largemouth bass, Micropterus salmoides & 1 & \\
\hline Green sunfish, Lepomis cyanellus & 1 & \\
\hline Brook silverside, Labidesthes sicculus & 1 & \\
\hline White bass, Morone chrysops & & 3 \\
\hline Freshwater drum, Aplodinotus grunniens & & 3 \\
\hline White crappie, Pomoxis annularis & & 2 \\
\hline Total & 518 & 37 \\
\hline
\end{tabular}

On 9 July, we returned at $1730 \mathrm{~h}$ to collect additional samples. While sampling, we observed freshly dead or moribund fish in our seine samples. After collecting several afflicted specimens, we ceased seining and collected all dead or moribund fish encountered as recommended by the American Fisheries Society (1992) and Labay and Buzan (1999). Dead or moribund fish were taken for approximately one hour from a 200-m river reach.

We collected 37 specimens that were dead or moribund. Death was observed in 5 species, including white perch, white bass (Morone chrysops), freshwater drum (Aplodinotus grunniens), white crappie (Pomoxis annularis), and river carpsucker (Carpoides carpio) (Table 1). White bass, white crappie, and freshwater drum are relatively uncommon in the North Fork Ninnescah River (Johnson, 2004) and were not collected by us on 8 July. The few individuals of these 3 species that we found on 9 July probably were more likely to be found because they were moribund or dead. All species collected on 8 July 2002 also were present in samples taken on 9 July 2002, although fish were not counted; thus, only a subset of the fish community was found dead or moribund.

We measured and recorded standard lengths of white perch collected on both days. Range of lengths for white perch collected on 8 July was 50 to $155 \mathrm{~mm}(n=12)$. Lengths of white perch collected dead or moribund on 9 July ranged from 52 to $265 \mathrm{~mm}(n=28)$. There was no significant difference between lengths of fish collected alive and dead or moribund $(t=1.54, d f=38, P=0.133)$. Range of standard lengths for other affected species collected on 9 July was: white bass, 187 to $222 \mathrm{~mm} \mathrm{(} n$ $=3$ ); freshwater drum, 261 to $315 \mathrm{~mm}(n=$ $3)$; white crappie, 104 to $109 \mathrm{~mm}(n=2)$; and river carpsucker, $360 \mathrm{~mm}(n=1)$.

It seems that high water temperature, which reached $38.0^{\circ} \mathrm{C}$ on $9 \mathrm{July}$, resulted in acute heat death of fish in the sampled portion of the river (Fig. 1). Maximum water temperature on 9 July was higher than on any previous day during 2002 at our sampling site and exceeded laboratory-determined thermal tolerances for nearly all of the species collected (Beitinger et al., 2000), especially among those species for which we collected dead and moribund specimens. Dissolved oxygen concentrations were greater than $5.0 \mathrm{mg} / \mathrm{L}$, so it is unlikely that dissolved oxygen was the cause of the fish kill. However, we cannot discount the possibility that some unmeasured and unidentified waterquality parameter was responsible for the fish kill. Because we observed individual fish through all stages of affliction, from initially behaving normally to losing equilibrium and ultimately dying, we are confident that the observed fish kill was due to conditions at this site.

Temperature tolerances vary widely among fish species, and among individuals within species there generally is a positive relationship between temperature tolerance and the temperatures to which fish recently have been exposed (Brett, 1956; Brown and Feldmeth, 1970). Because water temperatures in the North Fork Ninnescah River were elevated (up to $35^{\circ} \mathrm{C}$ ) for several days preceding the observed fish kill, it is not surprising that some species, for example, emerald shiner (Notropis atherinoides) and sand shiner, apparently were unaffected by high water temperatures on 9 July 2002, even though ambient water temperatures exceeded their laboratory-determined 


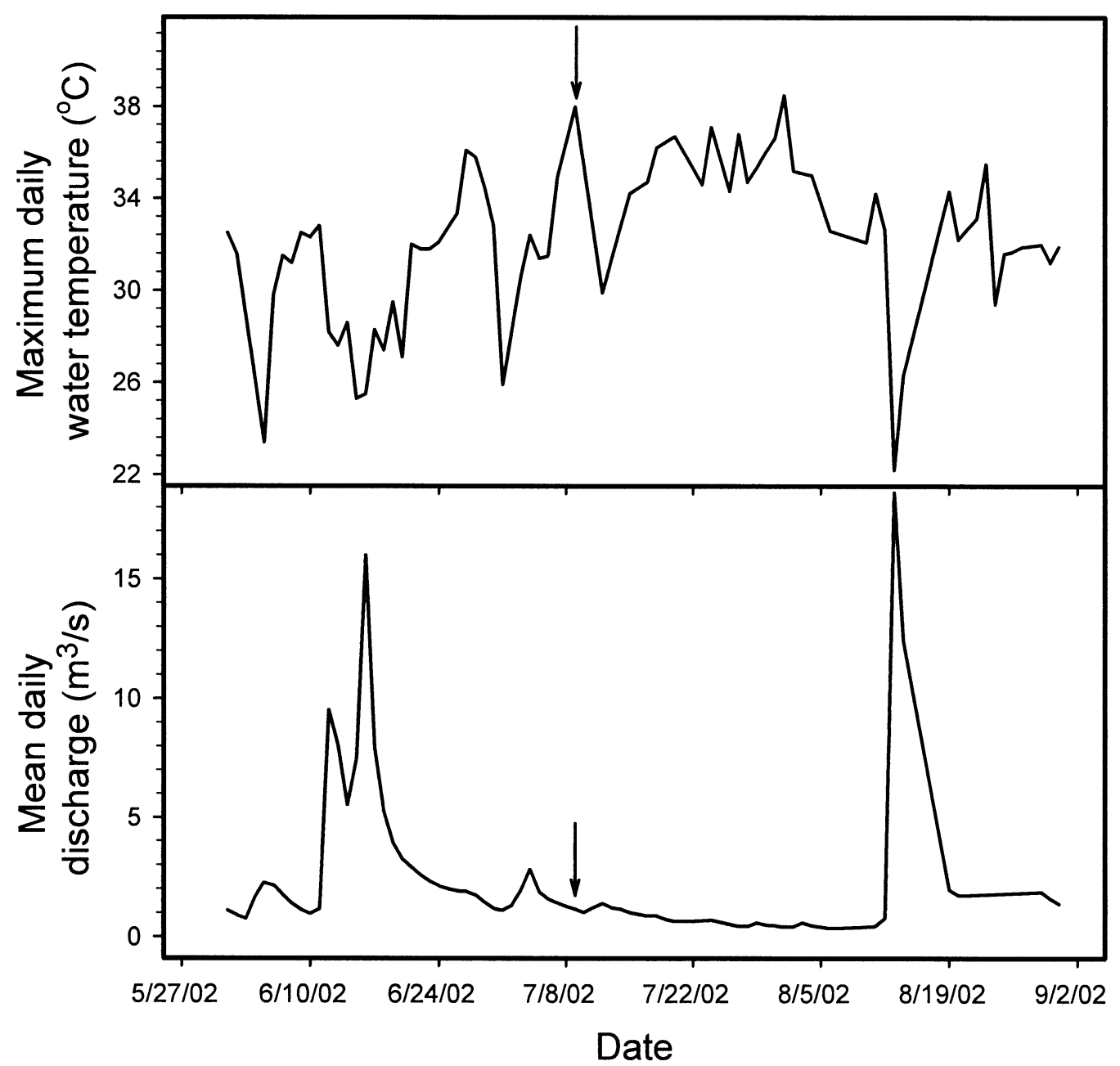

FIG. 1-Maximum daily water temperature $\left({ }^{\circ} \mathrm{C}\right)$ and mean daily discharge $\left(\mathrm{m}^{3} / \mathrm{s}\right)$ during June, July, and August 2002 in the North Fork Ninnescah River upstream from Cheney Reservoir, Reno County, Kansas. Data were obtained from a U.S. Geological Survey gaging station (\#07144780) located at the sampling site. Arrows indicate 9 July 2002, the day of the observed fish kill.

tolerances (Matthews and Maness, 1979; Smale and Rabeni, 1995). White perch is native to coastal drainages ranging from Nova Scotia south to South Carolina and is most abundant in the Hudson River and Chesapeake Bay (Burgess, 1980). White perch was inadvertently introduced into Cheney Reservoir in 1994 and apparently was the species most affected by high water temperatures in the North Fork Ninnescah River. Of the other species affected, 3 (white bass, white crappie, and freshwater drum) are native to drainages farther east in Kansas, but were not likely native to the Nin- nescah River basin (Cross, 1967; M. Eberle, pers. comm.). In western Kansas, which includes the Ninnescah River basin, these 3 species occur in impoundments and nearby stream segments (Cross, 1967). Thus, they might be more susceptible to heat stress when they move into shallow river segments during the summer and are unable to move into cooler microhabitats. Interestingly, it did not appear that size of fish was an important factor contributing to the death of white perch that we observed.

Reservoir construction, groundwater with- 
drawal, and irrigation diversions have resulted in extensive modifications of streams and rivers throughout the Great Plains. These changes have altered the discharge of these systems, which has caused streams and rivers to narrow and deepen and become confined to a single unbraided channel, in which a greater portion of the stream channel is shaded by gallery forests (Friedman et al., 1998). Associated with these changes in stream habitats has been a decrease in the distribution and abundance of several obligate stream fishes that usually are attributed to competition with, and predation by, species that historically were absent or uncommon in these streams (Cross and Moss, 1987; Pfleiger and Grace, 1987; Bonner and Wilde, 2000). Our observations suggest that the composition of the present fish assemblages might be structured, in part, by extremes in physical and chemical conditions. Among these, high water temperatures during summer periods of low discharge probably limit the ability of some species to inhabit these streams, even when they maintain some flow.

We thank F. Martinez, Jr. and G. P. Wilde for assistance in the field and laboratory. We thank G. Schneider, Kansas Department of Wildlife and Parks, for providing information on the introduction and establishment of white perch in Cheney Reservoir. C. Higgins and C. Chizinski provided constructive comments on the manuscript. C. Ortega provided resumen translation. This is contribution number $\mathrm{T}$ 9-1017 of the College of Agricultural Sciences and Natural Resources, Texas Tech University.

\section{Literature Cited}

AMERICAN Fisheries Society. 1992. Investigation and valuation of fish kills. American Fisheries Society, Special Publication 24, Bethesda, Maryland.

BAILEY, R. M. 1955. Differential mortality from high temperature in a mixed population of fishes in southern Michigan. Ecology 36:526-528.

Beitinger, T. L., W. A. Bennett, and R. W. MCCAUley. 2000. Temperature tolerances of North American freshwater fishes exposed to dynamic changes in temperature. Environmental Biology of Fishes 58:237-275.

Bonner, T. H., AND G. R. Wilde. 2000. Changes in the fish assemblage of the Canadian River, Texas associated with reservoir construction. Journal of Freshwater Ecology 15:189-198.

BRETT, J. R. 1956. Some principles in the thermal requirements of fishes. Quarterly Review of Biology 31:75-85.
Brown, J. H., AND C. R. Feldmeth. 1970. Evolution in constant and fluctuating environments: thermal tolerance of desert pupfish (Cyprinodon). Evolution 25:390-398.

Burgess, H. G. 1980. Morone americana (Gmelin). In: D. S. Lee, C. R. Gilbert, C. H. Hocutt, R. E. Jenkins, D. E. McAllister, and J. R. Stauffer Jr., editors. Atlas of North American freshwater fishes. North Carolina Biological Survey, Raleigh. Page 573.

Cross, F. B. 1967. Handbook of fishes of Kansas. University of Kansas, Museum of Natural History, Miscellaneous Publication Number 45:1-357.

Cross, F. B., AND R. E. Moss. 1987. Historic changes in fish communities and aquatic habitats in plains streams of Kansas. In: W. J. Matthews and D. C. Heins, editors. Community and evolutionary ecology of North American stream fishes. University of Oklahoma Press, Norman. Pages 155165.

Friedman, J. M., W. R. Osterkamp, M. L. SCOtt, AND G. T. Auble. 1998. Downstream effects of dams on channel geometry and bottomland vegetation: regional patterns in the Great Plains. Wetlands 18:619-633.

Huntsman, A. G. 1942. Death of salmon and trout at high temperature. Journal of the Fisheries Research Board of Canada 5:485-501.

Huntsman, A. G. 1946. Heat stroke in Canadian maritime stream fishes. Journal of the Fisheries Research Board of Canada 6:476-482.

Johnson, E. R. 2004. Population characteristics of the introduced white perch (Morone americana) in the Ninnescah River system and assessment of community structure after invasion. Unpublished M.S. thesis, Fort Hays State University, Hays, Kansas.

Labay, A. A., AND D. Buzan. 1999. A comparison of fish kill counting procedures on a small, narrow stream. North American Journal of Fisheries Management 19:209-214.

Matthews, W. J., and J. D. Maness. 1979. Critical thermal maxima, oxygen tolerance and success of cyprinid fishes in a southwestern river. American Midland Naturalist 102:374-377.

Matthews, W. J., E. Surat, and L. G. Hill. 1982. Heat death of orangethroat darter, Etheostoma spectabile (Percidae) in a natural environment. Southwestern Naturalist 27:216-217.

Mundahl, N. D. 1990. Heat death of fish in shrinking stream pools. American Midland Naturalist 123:40-46.

Pfleiger, W. L., AND T. B. GRace. 1987. Changes in the fish fauna of the lower Missouri River, 19401983. In: W. J. Matthews and D. C. Heins, editors. Community and evolutionary ecology of North American stream fishes. University of Oklahoma Press, Norman. Pages 166-177. 
Smale, M. A., And C. F. Rabeni. 1995. Hypoxia and hyperthermia tolerances of headwater stream fishes. Transactions of the American Fisheries Society 124:698-710.

Tramer, E. J. 1977. Catastrophic mortality of stream fishes trapped in shrinking pools. American Midland Naturalist 97:469-478.

Submitted 15 August 2003. Accepted 9 December 2005.

Associate Editor was Kevin Bestgen.

The Southwestern Naturalist vol. 51, no. 3 (Sept. 2006), pp. 397-401. 